\title{
ENERGY EFFICIENCY OF ELECTRIC DRIVE SYSTEMS AND ITS APPLICATION IN EDUCATION
}

\author{
Zlatin Zlatev ${ }^{1}$, Antoaneta Dimitrova ${ }^{1}$, Tanya Pehlivanova ${ }^{1}$, Plamen Duchev ${ }^{2}$ \\ ${ }^{1}$ Trakia University of Stara Zagora, Faculty of Technics and Technologies \\ Graf Ignatiev 38, 8602 Yambol, Bulgaria, e-mail: zlatin.zlatev@trakia-uni.bg \\ ${ }^{2}$ American University in Bulgaria, Blagoevgrad, Bulgaria \\ e-mail: p2duchev@abv.bg
}

\begin{abstract}
Motors are the most important driving components of industrial and consumer products. Therefore improving the energy efficiency of their work is an important environmental and economic problem. Systematic review of laboratory equipment for training in energy efficiency is made for the integrated influence between curricular practical training and current requirements of the industry. The application of various training tools opens up new possibilities for adapting the teaching methods in universities to the learning style of today's students. The presented system is improved with application of additional software and hardware components from other manufacturers.
\end{abstract}

Keywords: Electric motor, Energy efficiency, Lucas Nuelle, Training system, Education.

\section{INTRODUCTION}

The electromechanical systems are widespread. They are used in many areas of everyday life. Therefore improving the energy efficiency of their work is an important environmental and economic issue. To ensure higher efficiency of these systems requires a good knowledge of the interaction between all elements thereof, which is important in their design and operation $[3,8]$.

Academics are encouraged to continually develop engines with high energy efficiency. Scientists and researchers are principally engaged in theoretical research, and manufacturers - to create new products and components in response to the global trend of energy efficient electric motors and electric drives, which are regarded as a common energy system and improving the related standards [6, 9].

In terms of the training is important to have a relationship and integration between curriculum based on scientific postulates, as well as industry-oriented obtaining added value [1]. The practical training must adapt to the introduction of new technologies, the level of technical innovation and prepares students for interdisciplinary realization and lifelong learning $[7,14$, $15,16]$.

The aim of this report is to summarize the methodology for training in the field of energy efficiency of electric drives and to propose an option for further improvement of the existing laboratory system for training and research in this area.

\section{LABORATORY EQUIPMENT FOR TRAINING IN ENERGY EFFICIENCY OF ELECTRICAL MACHINES}

Crucial to ensure effective learning is used laboratory facilities. In this aspect specializing Department of Electrical Engineering, Electronics and Automation [11] is trying to implement in the learning process advanced technologies, devices and systems of leading companies in the field.

IRTIIE Vol. 4, No. 1, 2016 ISSN 1314-8788 (print), ISSN 1314-8796 (online), doi: 10.15547/artte.2016.01.004 


\section{ARTIIE Ipplied Researrches in Technics, Technologies ind Educition Journal of the Faculty of Technics and Technologies, Trakia University https://sites.google.com/a/trakia-uni.bg/artte/}

Education in the Faculty of Technics and Technologies of Yambol is aimed at learning competencies for applying the existing methodologies and regulations $[4,5,10,18]$, related to the specific area energy efficiency of electric drives. To meet the requirements for preparation of competitive specialists for the labor market was established laboratory equipped with operating units and models in which students conduct experiments and research with given by the lecturer terms and conditions.

The exercises are related to solving real problems for the design and testing of energy efficient electromechanical systems, including awareness-raising and seeking appropriate solutions through research, calculations, simulations, optimization and testing results on real experimental arrangement.

Used equipment are customary for each lab-related training in automated electric drives. The use of such equipment has the advantage that the exercises which are implemented are practical and implemented by simulating real production situations $[13,17]$. Thus, students develop skills in decision-making and behavior model in terms of shortage of time taking into account the parameters and requirements of production.

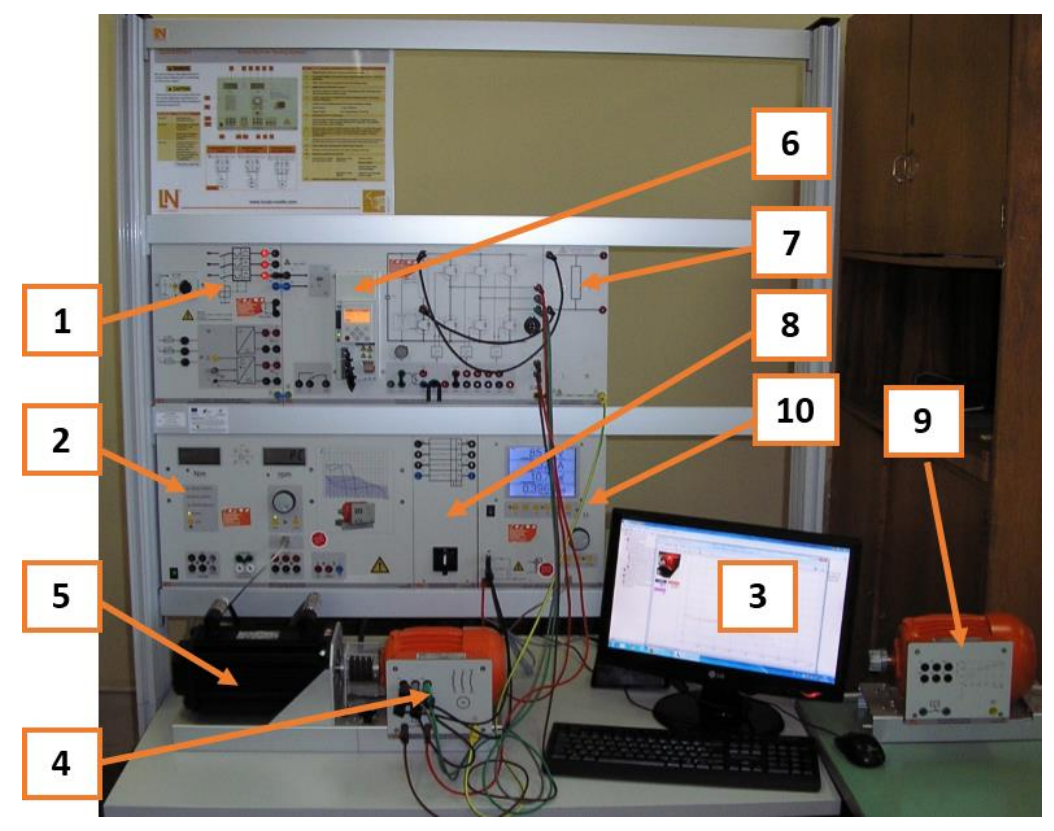

Figure.1. Laboratory stand for study of the energy efficiency of electric drives

1-Power supply unit; 2-Control and testing of servomotors; 3-PC with software; 4-Standard motor; 5-Servo motor; 6-Frequency Inverter; 7-Protective resistor; 8-Galvanic circuit breaker; 9-energy efficient motor class IE3; 10-USB multimeter

In Figure 1 it is represented common type of laboratory setup for Study of the energy efficiency of electric drives. The staging is based on a modular principle. Every element of power and control of the electromechanical system is packaged in a separate module.

The power supply module provides three-phase and single-phase AC and DC power supply for different types of electrical machines, as well as synchronous ones.

The module for control and testing of servomotors is used for testing of electrical machines and drives. It consists of a device for digital control, brake, automatic and manual synchronization. Thermal protection is provided for the controlled machine. The connection of this module to a PC is via USB interface. The control software is "Active Servo" in which is possible to obtain characteristics of the test motor: speed; mechanical, complete, active,

IRTTIE Vol. 4, No. 1, 2016 ISSN 1314-8788 (print), ISSN 1314-8796 (online), doi: 10.15547/artte.2016.01.004 


\section{IRTTIE}

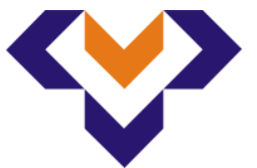

Ipplied Researl'ches in Technics, Technologies ind Bducation

Journal of the Faculty of Technics and Technologies, Trakia University https://sites.google.com/a/trakia-uni.bg/artte/

reactive power; voltage and current per phase; power factor $(\cos \varphi)$; efficiency. Figure 2 is an example for determining the mechanical characteristics and operating point of electromechanical system with three-phase induction motor.

Through the software product can be simulated electromechanical systems such as pump, fan, compressor, lifting machine, winding machine, inertial wheel. Can be determined the regime parameters of electromechanical system with various types and value of motor loads.

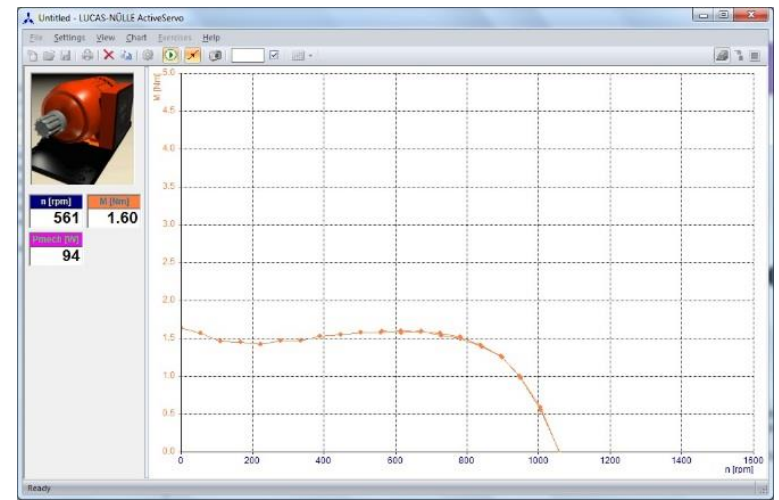

a) obtaining of mechanical characteristic

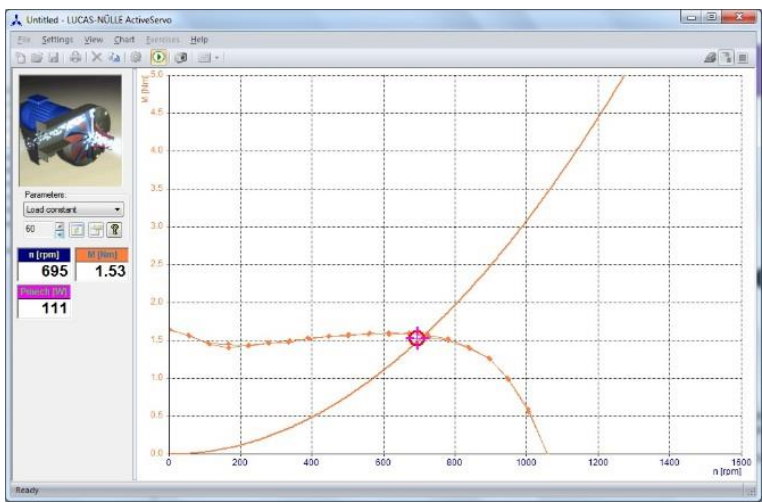

b) determination of optimal operating point

Figure.2. Working screens of the software „Active Servo“

Through the multimeter with a USB connection to a PC can be measured: voltage; electricity; active, full, reactive power; power factor.

The block with frequency inverter is based on the device Lenze 8400 [20]. This module is designed specifically for training and research. The inverter operates with a linear or quadratic $\mathrm{V} / \mathrm{f}$ characteristic and vector control. Management and assignment of the inverter is done with potentiometer, by the operator display or via the digital inputs. The frequency inverter can be controlled through an industrial network of field level CANopen. Can be added extensions for EtherCAT, EtherNet/IP, POWERLINK, PROFIBUS, PROFINET.

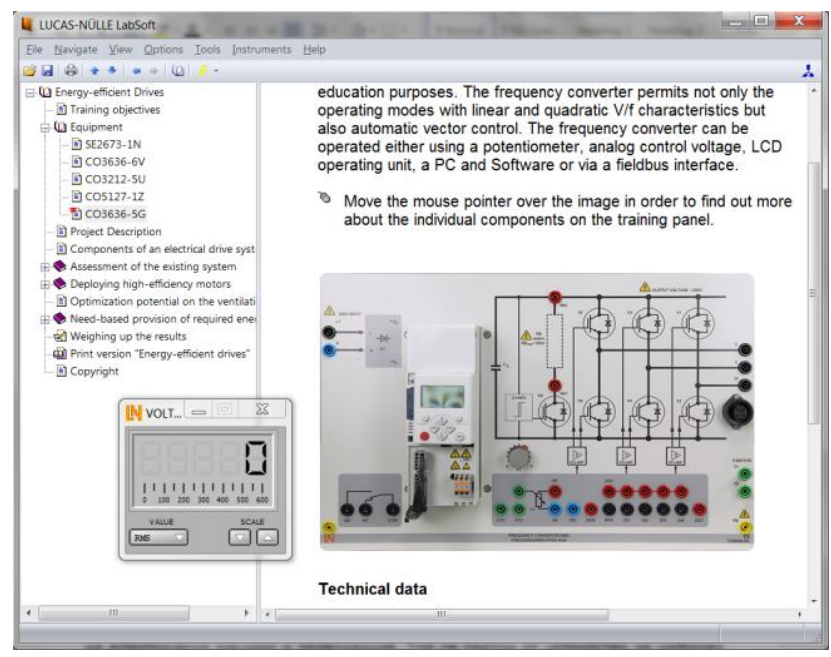

Figure 3. Screen of the interactive environment "LabSoft" with virtual instrument „Multimeter"

IRTIIE Vol. 4, No. 1, 2016 ISSN 1314-8788 (print), ISSN 1314-8796 (online), doi: 10.15547/artte.2016.01.004 


\section{ARTTIE $Y$}

Ipplied Researl'ches in Technics, Technologies ind Bducation

Journal of the Faculty of Technics and Technologies, Trakia University https://sites.google.com/a/trakia-uni.bg/artte/

The training course is managed with multimedia interactive environment "LabSoft" [21]. In this software (Figure 3) are provided virtual instruments for measurements in real time and generate output signals. The work area is divided into two main window. The left side is the course content in the form of hyperlinks to the exercises, which are displayed in the right pane.

\section{SUMMARY OF THE CONTENT OF THE COURSE ON ENERGY EFFICIENCY OF ELECTRIC MOTORS}

Training provided by the manufacturer methodology is implemented in the usual deductive approach - „From the general to the particular“.

Table 1. Summary of the training course on the energy efficiency in electric drives

\begin{tabular}{|c|c|c|}
\hline \multicolumn{2}{|c|}{ Stage } & Description \\
\hline \multicolumn{2}{|c|}{ Basic questions. Topicality } & $\begin{array}{l}\text { Justification of the topicality of the problem of application } \\
\text { of energy-efficient electromechanical systems }\end{array}$ \\
\hline \multicolumn{2}{|c|}{ Description of the equipment } & Presentation of the equipment as described in Figure 1 \\
\hline \multicolumn{2}{|c|}{ Description of the project } & $\begin{array}{l}\text { Characteristics of the electric drives system of a } \\
\text { particular object, such as a fan, pump, compressor, etc. }\end{array}$ \\
\hline \multicolumn{2}{|c|}{ Block diagram of the system } & $\begin{array}{l}\text { Description of the system as a whole and its individual } \\
\text { elements }\end{array}$ \\
\hline \multirow{6}{*}{$\begin{array}{l}\text { Assessment of } \\
\text { the existing } \\
\text { system }\end{array}$} & Determination of losses & $\begin{array}{l}\text { Review and description of the losses in the individual } \\
\text { elements and of the system as a whole }\end{array}$ \\
\hline & Determine the required power & $\begin{array}{l}\text { Determining the necessary capacities, negative impact of } \\
\text { oversized motor, opportunities for energy savings }\end{array}$ \\
\hline & $\begin{array}{l}\text { Determination of the operating point } \\
\text { of the motor }\end{array}$ & $\begin{array}{l}\text { Determination of the operating point, required power and } \\
\text { efficiency of the system }\end{array}$ \\
\hline & $\begin{array}{l}\text { Determination of losses in induction } \\
\text { motor by equivalent circuit }\end{array}$ & $\begin{array}{l}\text { Calculating the parameters of the replacement scheme } \\
\text { catalog data on motor nameplate }\end{array}$ \\
\hline & $\begin{array}{l}\text { Determining the optimum operating } \\
\text { point of stable collaborative work }\end{array}$ & $\begin{array}{l}\text { Studying and analyzing the important characteristics of } \\
\text { asynchronous motors as setpoint and power required }\end{array}$ \\
\hline & $\begin{array}{l}\text { Direct and indirect determining the } \\
\text { maximum usable capacity of the } \\
\text { motor }\end{array}$ & $\begin{array}{l}\text { Theoretical justification for experimental and numerical } \\
\text { determination of nominal and critical motor parameters }\end{array}$ \\
\hline \multirow{5}{*}{$\begin{array}{l}\text { Implementation } \\
\text { of energy } \\
\text { efficient motors }\end{array}$} & $\begin{array}{l}\text { Specifics in the design of energy } \\
\text { efficient motors }\end{array}$ & $\begin{array}{l}\text { Use of energy efficient materials, reducing losses, } \\
\text { comparative analysis of standard and energy efficient } \\
\text { motor }\end{array}$ \\
\hline & Classification of motors & $\begin{array}{l}\text { Comparative analysis of the energy efficiency standards } \\
\text { of electric motors }\end{array}$ \\
\hline & $\begin{array}{l}\text { Attempted preparation of the } \\
\text { characteristics of energy-efficient } \\
\text { motors }\end{array}$ & $\begin{array}{l}\text { Practical task of testing of nominal parameters of the } \\
\text { motor }\end{array}$ \\
\hline & $\begin{array}{l}\text { Identification of potential savings at } \\
\text { partial and full load motor }\end{array}$ & $\begin{array}{l}\text { Comparing the costs of operation of standard and } \\
\text { efficient electric motor. Determination of the period for } \\
\text { return on investments }\end{array}$ \\
\hline & $\begin{array}{l}\text { Opportunities for optimization of } \\
\text { electromechanical system }\end{array}$ & Theoretical justification of energy efficient design \\
\hline \multirow{3}{*}{$\begin{array}{l}\text { Efficient use of } \\
\text { energy }\end{array}$} & $\begin{array}{l}\text { Determining the optimal variant for } \\
\text { actuation and control of the system }\end{array}$ & $\begin{array}{l}\text { Choosing a method of control of the motor with } \\
\text { adjustable speed }\end{array}$ \\
\hline & $\begin{array}{l}\text { Operation of the system with } \\
\text { frequency inverter }\end{array}$ & \multirow{2}{*}{$\begin{array}{l}\text { Determining and setting the parameters of a frequency } \\
\text { inverter. Comparative analysis of direct on-line start of } \\
\text { the motor and under control with frequency inverter }\end{array}$} \\
\hline & $\begin{array}{l}\text { Determining the optimal parameters } \\
\text { of the frequency inverter }\end{array}$ & \\
\hline \multicolumn{2}{|c|}{ Analysis of results and conclusions } & $\begin{array}{l}\text { Analysis of results and assessment of the possibilities for } \\
\text { energy savings in the use of standard and energy } \\
\text { efficient motors. Possibility of upgrading of existing } \\
\text { electromechanical system with energy efficient solutions }\end{array}$ \\
\hline
\end{tabular}

IRTIIE Vol. 4, No. 1, 2016 ISSN 1314-8788 (print), ISSN 1314-8796 (online), doi: 10.15547/artte.2016.01.004 


\section{ARTIL \\ $Y^{3}$ \\ Ipplied Resseirthes in Technics, Technologies and Bductition \\ Journal of the Faculty of Technics and Technologies, Trakia University https://sites.google.com/a/trakia-uni.bg/artte/}

In Table 1 it is made summarized contents of developed by a team of the company "LucasNuelle" [12] training course on the energy efficiency of electric drives. The course consists of research into energy efficiency of ventilation system with three fans powered by three-phase asynchronous motors.

The training is organized in groups of tasks, preceded by theoretical reasoning and presentation of the problem to be solved in general form. Followed by numerical and/or experimentally determination the parameters of the motor, and finally a summary of the results. After each exercise is designed test to consolidation and examination.

The presented course has the advantage of using modern multimedia and interactive tools for training the students. In software product is embedded content with hyperlinks to the exercises and the ability to use virtual instruments for measuring parameters of electrical machines. There is simulation used in the practice of electromechanical systems.

One disadvantage of this computer integrated system is that the data was plotted as a raster graphics, which hampers their direct use for processing and analysis. In the software is a possibility resulting graphics can be copied as an image file and stored on the PC or inserted into word processing applications such as MS Word or Open Office Writer and others. Connectors are provided to connect external measuring devices, such as multimeters, oscilloscopes etc.

\section{IMPLEMENTATION OF OF SOFTWARE AND MEASURING EQUIPMENT FROM OTHER DEVELOPERS FOR OBTAINING AND PROCESSING OF DATA}

Improvement of the system is in obtaining graphic data of measurements with application of software from other developers with tools for extracting points from raster graphics and converting them into vector. These are published on the website of Mathworks and can easily be run in software product Matlab [22]. Suitable programming tool is Grabit (Figure 4). The program offers a form defining the minimum and maximum value by $x$ and $y$ axes, review of the received graphic recording in a file. The coordinates are obtained by clicking on the image points, which are part of the processed chart [23].

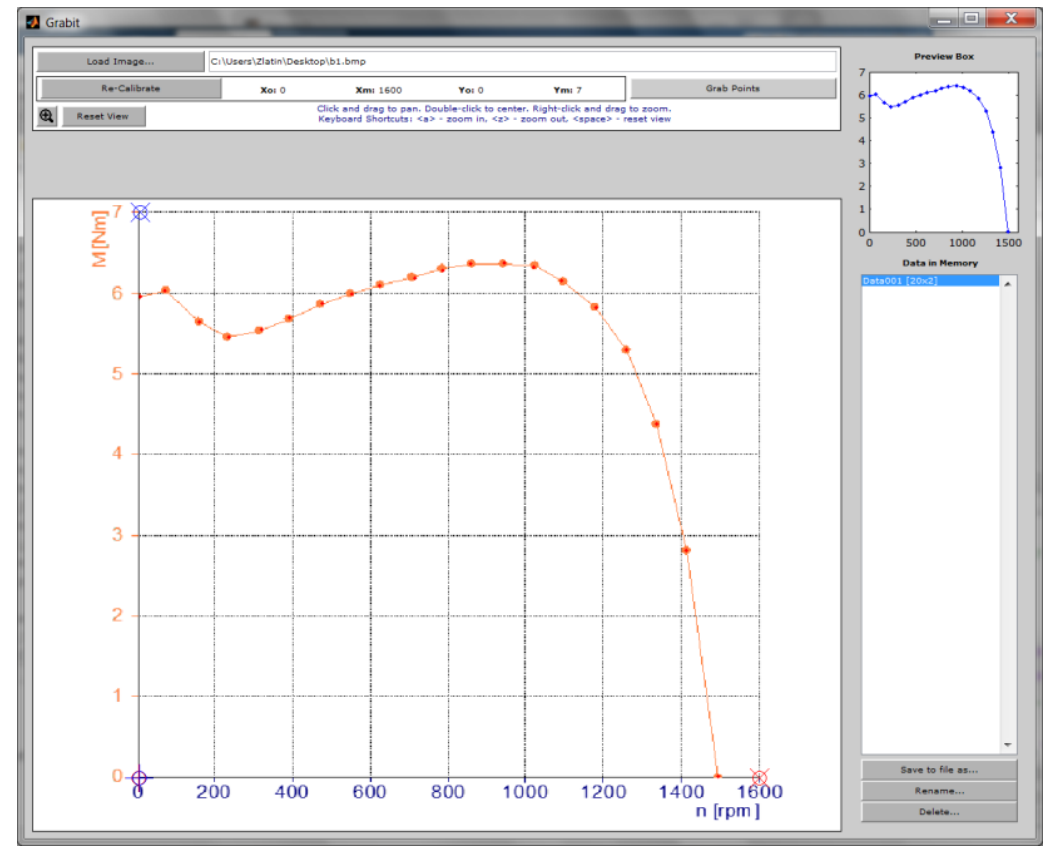

Figure 4. Form for obtaining the values from chart "Grabit"

IRTTIL Vol. 4, No. 1, 2016 ISSN 1314-8788 (print), ISSN 1314-8796 (online), doi: 10.15547/artte.2016.01.004 


\section{IRTIIE}

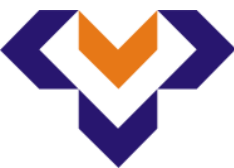

Ipplied Reseirlches in Technicis, Technologies and Bductition

Journal of the Faculty of Technics and Technologies, Trakia University https://sites.google.com/a/trakia-uni.bg/artte/

The resulting characteristics of the motor can be presented as the Principal components, Wavelet coefficients or a combination thereof, to use methods for classification with Support vectors machines, Neural networks, Kalman filter, Decision tree and others. For example, in determining the losses in electric motors, which are related to energy-efficient use as described in $[2,19]$.

On the panel of the module for control and testing of servo motors are displayed connectors for measuring speed and torque. These parameters of the motor are displayed in the form of voltage proportional to them and under the connectors are specified conversion coefficients to convert measured voltage to speed and torque.

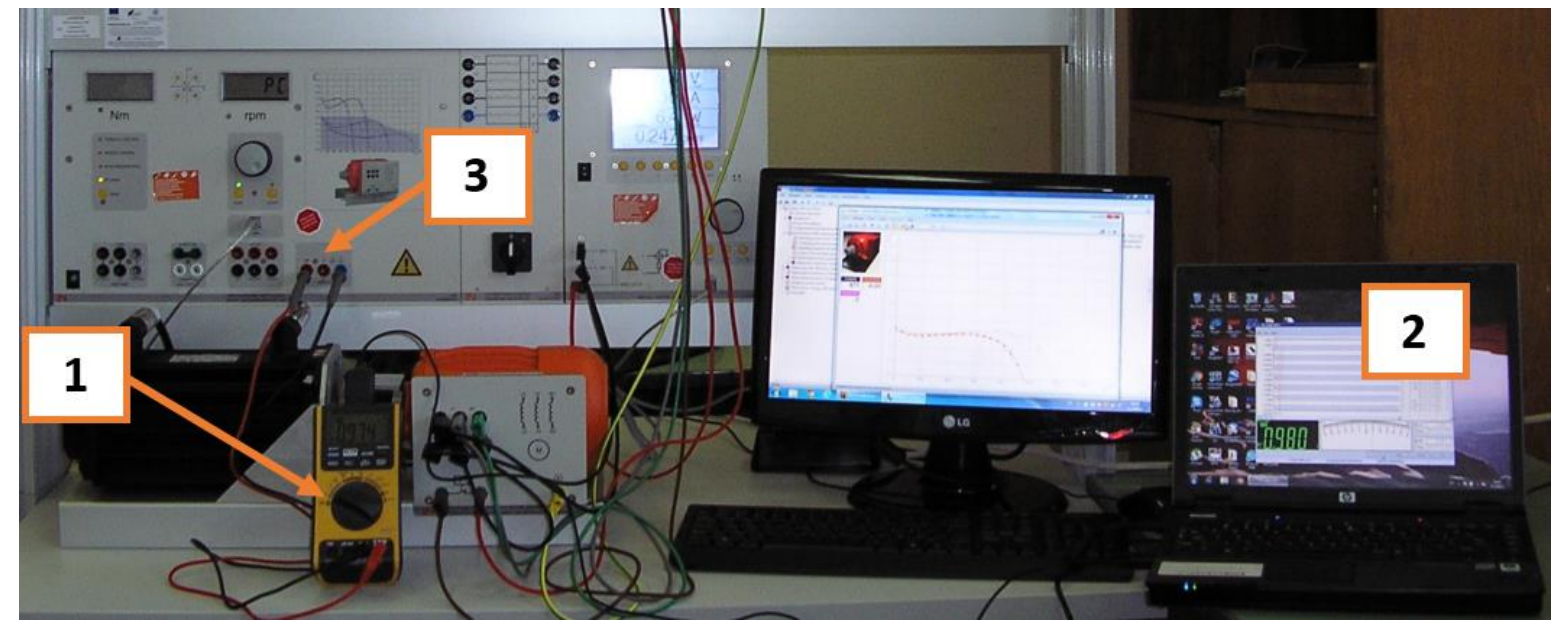

Figure 5. Measurement of speed and torque with USB multimeter

1-Multimeter with USB interface; 2-PC with PC-Link software; 3-Connectors for measuring speed and torque

Figure 5 is an example of recording of torque through multimeter with USB interface VA18B. This multimer is connected to a personal computer. The system for external obtaining of motor characteristics consists PC installed with the following software: PC-Link - Direct reading and recording the readings of multimer; MS Excel - data import from software of the meter and export to Matlab; Matlab - Importing data from MS Excel for the purpose of processing by the methods presented above.

\section{CONCLUSIONS}

Technology development in the field of energy-efficient electric drives require adaptation of educational content to them.

An analysis and systematic review is made of hardware and software content of training courses of laboratory setup for testing the energy efficiency of electric motors. The results of this analysis indicate that additional software and measuring equipment is necessary for application of this equipment for research purposes.

By summarizing the methodology for conducting exercises in the field of energy efficiency of electric drives are systematized different options allowing students to find appropriate solutions in case of problems in this area.

Software and measuring instrument are adapted for obtaining data of motor characteristics in vector format. From these characteristics can easily be retrieved features that can be used as input to the classifiers.

IRTIIE Vol. 4, No. 1, 2016 ISSN 1314-8788 (print), ISSN 1314-8796 (online), doi: 10.15547/artte.2016.01.004 


\section{ARTTE $Y$}

Ipplied Reseirlches in Technicis, Technologies and Bductition

Journal of the Faculty of Technics and Technologies, Trakia University https://sites.google.com/a/trakia-uni.bg/artte/

\section{ACKNOWLEDGEMENTS}

The studies in this report are supported by grant 4FTT/30.04.2015 "Research on the energy efficiency of the electric drives"

\section{LITERATURE}

[1] Belyaeva A. P. Theoretical problems of development of vocational education, Proceedings, 1991, pp.136 (original is in Russian).

[2] Georgoulas G., M. O. Mustafa, I. P. Tsoumas, J. A. Antonino-Daviu, V. ClimenteAlarcon, C. D. Stylios, G. Nikolakopoulos. Principal Component Analysis of the start-up transient and Hidden Markov Modeling for broken rotor bar fault diagnosis in asynchronous machines.

[3] Hristova-Tsankova M. Study the energy efficiency of induction motors in electric drives, PhD Thesis, Rousse, 2013 (original is in Bulgarian).

[4] IEC 60034-2-1 Edition 2.0 Rotating electrical machines - Part 2-1 Standard methods for determining losses and efficiency from tests (excluding machines for traction vehicles), 2014, IEC International Electrical Commission.

[5] IEEE Std 112 IEEE Standard Test Procedure for Polyphase Induction Motors and Generators, 2004, IEEE Power Engineering Society, 79.

[6] IMS Research, Motors \& drives global market update, September 2011.

[7] Jidkova E. V. Diagnostics of educational achievements in terms of credit-rating system of training of students in technical university, PhD Thesis, Moscow, 2006, pp. 21-37. (original is in Russian).

[8] Keremidchieva K. Energy efficiency of electric motors, Journal of Proceedings of the Technical University - Sliven, ISSN 1312-3920, vol. 5, 2015. (original is in Bulgarian).

[9] Keremidchieva K. Innovations in electric motors with efficiency class IE1, IE2 and IE3, Journal of Proceedings of the Technical University - Sliven, ISSN 1312-3920, vol. 5, 2015. (original is in Bulgarian).

[10] Lu S-M. A review of high-efficiency motors: Specification, policy, and technology, Renewable and Sustainable Energy Reviews, No 59, (2016), pp. 1-12.

[11] Nedeva V., D. Nedev, Architecture for Integrated Management Information System for Trakia University of Stara Zagora, International Conference on Technics, Technologies and Education ICTTE 2014, ISSN 1314-9474, pp. 327-337.

[12] Neumann T., R. Linnertz. EEM 11 "Energy-efficient Drives", SO2800-1F Version 1.0, Lucas-Nülle $\mathrm{GmbH}$.

[13] Nikovski PI. Comparative analysis of methods for measuring the the energy efficiency of induction motors in standard IEC 60034-2-1 Part 1, Science \& Technologies, Technical studies, Vol. V, No 4, 2015, pp. 79-83.

[14] Pehlivanova M., Ducheva Zl. The interdisciplinarity in the training of engineers - a condition for solving the global problems of the humanity, The 9th International Conference on Virtual Learning ICVL 2014, University of Bucharest, Faculty of Psihology and Educational Sciences, Proceedings of ICVL 2014 (ISSN 1844-8933).

[15] Pehlivanova M., Ducheva Zl. The role of university professors for the interdisciplinary education of the engineers, The 9th International Conference on Virtual Learning ICVL 2014, University of Bucharest, Faculty of Psihology and Educational Sciences, Proceedings of ICVL 2014 (ISSN 1844-8933).

[16] Pehlivanova, M., Zl. Ducheva. Training in a virtual learning environment in the theoretical module - a factor for development of "responsible" driver, The 6th International

IRTIIE Vol. 4, No. 1, 2016 ISSN 1314-8788 (print), ISSN 1314-8796 (online), doi: 10.15547/artte.2016.01.004 


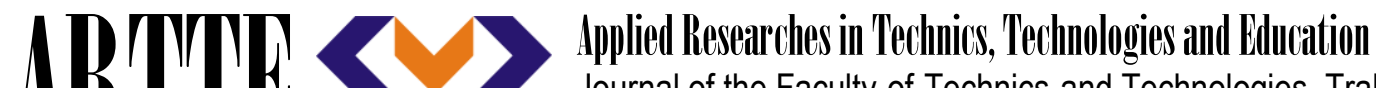 Journal of the Faculty of Technics and Technologies, Trakia University https://sites.google.com/a/trakia-uni.bg/artte/}

Conference on Virtual Learning ICVL 2011, University of Bucharest and "Babeş-Bolyai" University of ClujNapoca, Romania, 2011, pp. 275-280.

[17] Popov G., B. Kostov, K. Klimentov. Factors affecting the efficient use of energy in pump and fan systems, Proceedings of Rousse university, vol. 49, No 1.2, 2010, ISSN 13113321 , pp. 40-46. (original is in Bulgarian).

[18] Regulation (EC) № 640/ 2009 on the application of Directive 2005/ 32/ EC of the European Parliament and of the Council with regard to ecodesign requirements for electric motors, the Official Journal of the EU, 23.07.2009, pp. 26-34.

[19] Sawitri D., I. Ketut, E. Purnama, M. Ashari. Detection of electrical faults in induction motor fed by inverter using support vector machine and receiver operating characteristic, Journal of Theoretical and Applied Information Technology, 15 June 2012, Vol. 40, No.1, ISSN: 1992-8645, pp. 16-22.

[20] http://www.lenze.com/ (available on 20.12.2015).

[21] http://www.lucas-nuelle.com/ (available on 10.12.2015).

[22] http://www.mathworks.com/matlabcentral/fileexchange/ (available on 15.12.2015).

[23] http://www.mathworks.com/matlabcentral/fileexchange/7173-grabit (available

on 21.12.2015).

IRTIIE Vol. 4, No. 1, 2016 ISSN 1314-8788 (print), ISSN 1314-8796 (online), doi: 10.15547/artte.2016.01.004 